\title{
Import of Peroxisomal Matrix and Membrane Proteins
}

\author{
S. Subramani, Antonius Koller, and William B. Snyder \\ Department of Biology, University of California, San Diego, La Jolla, \\ California 92093-0322; e-mail: ssubramani@ucsd.edu
}

\begin{abstract}
Key Words organelle biogenesis, protein targeting, peroxisome targeting signals, peroxin interactions, membrane assembly
\end{abstract}

- Abstract This review summarizes the progress made in our understanding of peroxisome biogenesis in the last few years, during which the functional roles of many of the 23 peroxins (proteins involved in peroxisomal protein import and peroxisome biogenesis) have become clearer. Previous reviews in the field have focussed on the metabolic functions of peroxisomes $(1,2)$, aspects of import/biogenesis (3-7), the role of peroxins in human disease $(2,8)$, and involvement of the endoplasmic reticulum in peroxisome membrane biogenesis (9-11) as well as the degradation of this organelle $(5,12)$. This review refers to some of the earlier work for the sake of introduction and continuity but deals primarily with the more recent progress. The principal areas of progress are the identification of new peroxins, definition of protein-protein interactions among peroxins leading to the recognition of complexes involved in peroxisomal protein import, insight into the biogenesis of peroxisomal membrane proteins, and, of most importance, the elucidation of the role of many conserved peroxins in human disease. Given the rapid progress in the field, this review also highlights some of the unanswered questions that remain to be tackled.

\section{CONTENTS}

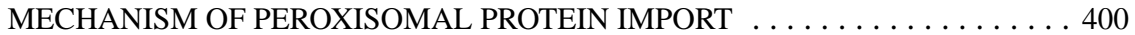

Import of Matrix Proteins . . . . . . . . . . . . . . . . . . . . 400

Unanswered Questions Regarding Peroxisomal Matrix Protein Import . . . . . . . . 404

Import and Assembly of Peroxisomal Membrane Proteins . . . . . . . . . . . . . . . . . . . . 405

Unanswered Questions Regarding PMP Biogenesis . . . . . . . . . . . . . . . . . . . 409

Is There a Quality Control Pathway for Peroxisomal Membrane Proteins? . . . . . 409

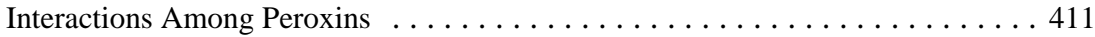

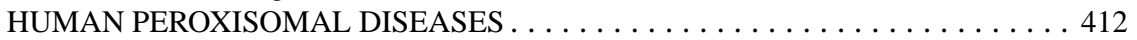

Disorders Caused by Peroxin Mutations . . . . . . . . . . . . . . . . 412

Disorders Resulting from Mutations in Proteins Other Than Peroxins . . . . . . . . 413 


\section{MECHANISM OF PEROXISOMAL PROTEIN IMPORT}

\section{Import of Matrix Proteins}

It is a generally accepted fact that the import of most proteins into the peroxisomal matrix is signal mediated. Two peroxisome-targeting signals (PTSs), termed PTS1 (a conserved C-terminal tripeptide sequence) and PTS2 (a nonapeptide sequence located near the $\mathrm{N}$ terminus or at internal locations in proteins), account for the transport of most polypeptides into the peroxisome matrix (5; Figure 1). These signals on matrix proteins are recognized in the cytosol by soluble PTS receptors, Pex5p for PTS1 proteins (13-20) and Pex7p for PTS2 proteins (21-28). The receptor-cargo complexes then dock at the peroxisomal membrane with the docking proteins, Pex13p $(19,29-32)$ and Pex14p $(19,33-36)$, each of which apparently forms distinct complexes with Pex5p and Pex7p (32; Figure 2).

Pex13p is an integral peroxisomal membrane protein (PMP) whose $\mathrm{N}$ and $\mathrm{C}$ termini are in the cytosol (32). The C-terminal portion of Pex13p contains an SH3 domain that appears to be critical for the binding to Pex5p (29-31). This fact has been demonstrated by using the yeast two-hybrid system, by studies showing the binding of Pex $5 p$ to the large, cytosolic, C-terminal domain of Pex13p containing the SH3 domain (29-31), and by the use of coimmunoprecipitation experiments (32). These studies also showed that the binding of Pex5p to Pex13p is direct.

It is interesting that the C-terminal SH3 domain of Pex13p is involved in interactions with both Pex5p and Pex14p (Figure 3). The reverse transcriptase (RT) loop within the SH3 domain of Pex 13p interacts with Pex 14p via a PXXP sequence (a type II, SH3 domain-binding motif) on the latter $(32,33,37)$. Mutations in the

\section{MATRIX PROTEINS}
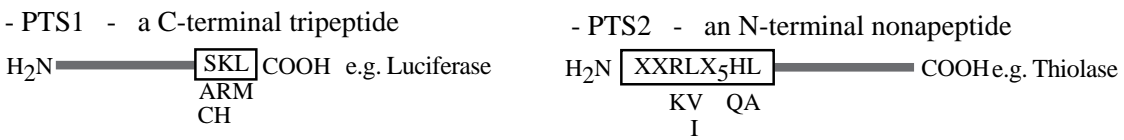

\section{MEMBRANE PROTEINS}

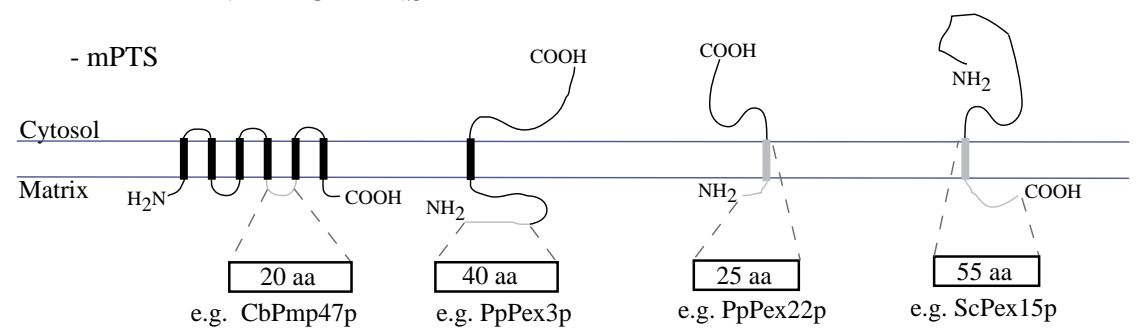

Figure 1 Targeting signals used by peroxisomal proteins. The PTSs are located in the boxes along with the consensus sequences, where applicable, and conserved variants are shown below these sequences. In each case, an example of a protein containing the PTS is given. 


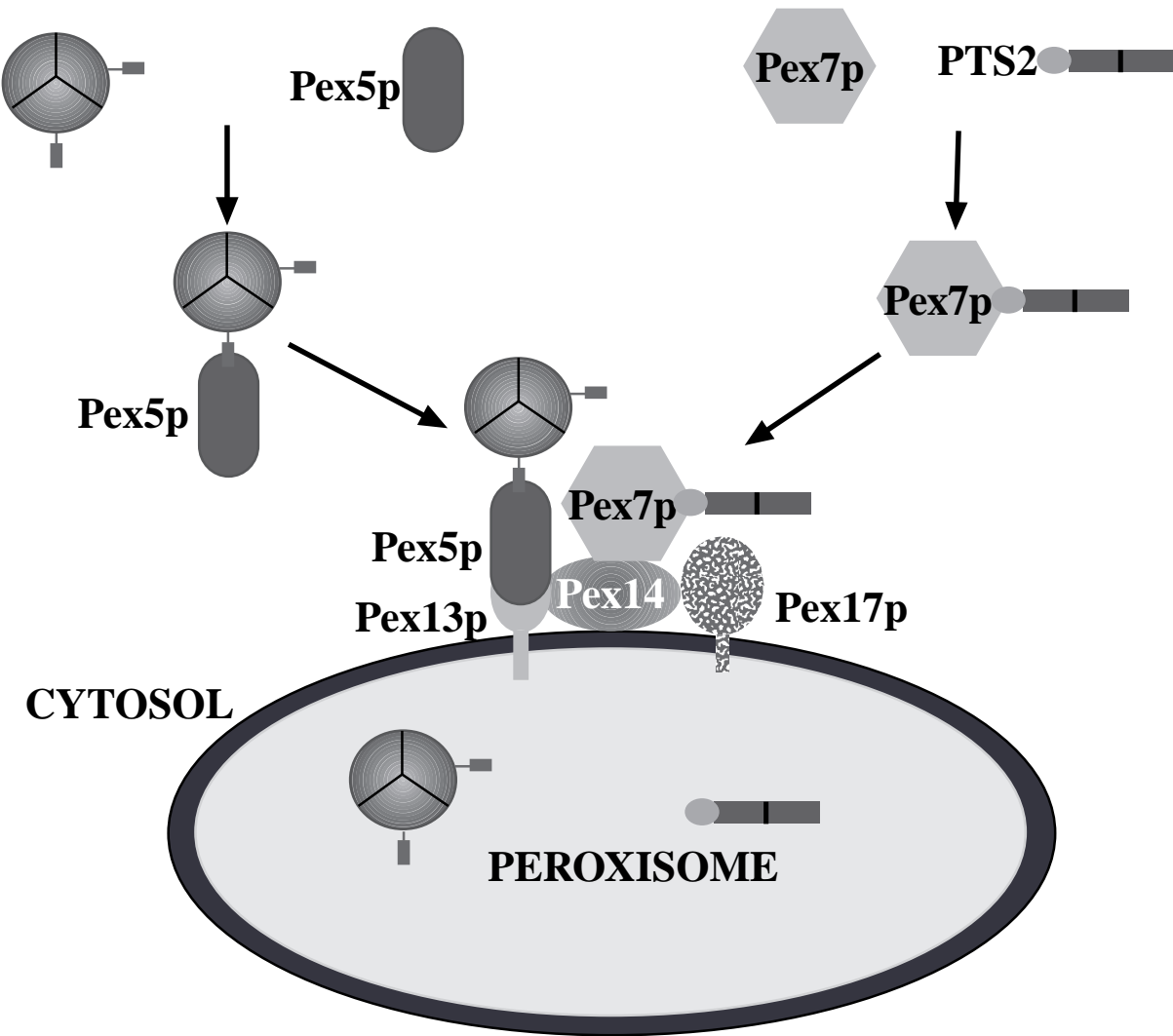

Figure 2 Model for the early stages in the import of peroxisomal matrix proteins. PTS1- and PTS2-containing proteins are recognized in the cytosol by specific receptors, Pex $5 p$ and Pex7p, respectively. These receptor-cargo complexes bind to the surface of the peroxisomal membrane via Pex13p and Pex14p. The latter forms a complex with Pex5p, Pex7p, Pex13p, and Pex17p, as shown, as well as with Pex3p, Pex8p, and itself (not shown). Pex13p forms complexes with Pex5p and Pex14p, as shown, but also with Pex7p (directly or indirectly) and Pex19p (not shown). Oligomeric proteins comprising some subunits with a PTS and others lacking one can enter the peroxisome because protein unfolding and monomerization are not essential for import of matrix proteins. Other cytosolic proteins, PMPs, and intraperoxisomal proteins implicated in import are described in the text.

RT loop of Pex13p that disrupt interactions with Pex14p do not impair the ability of Pex13p to interact with Pex5p. Thus, the binding interactions of Pex5p and Pex14p with the SH3 domain of Pex13p must be at least partially nonoverlapping (32). No PXXP motif has been found on Pex5p, so the peptide sequences involved in the Pex 5p-Pex 13p interaction remain obscure. One cannot rule out the presence of noncanonical binding sites for SH3 domain proteins as described recently for the interaction of an SH3 protein called Eps8 with a PXXDY sequence (38). 


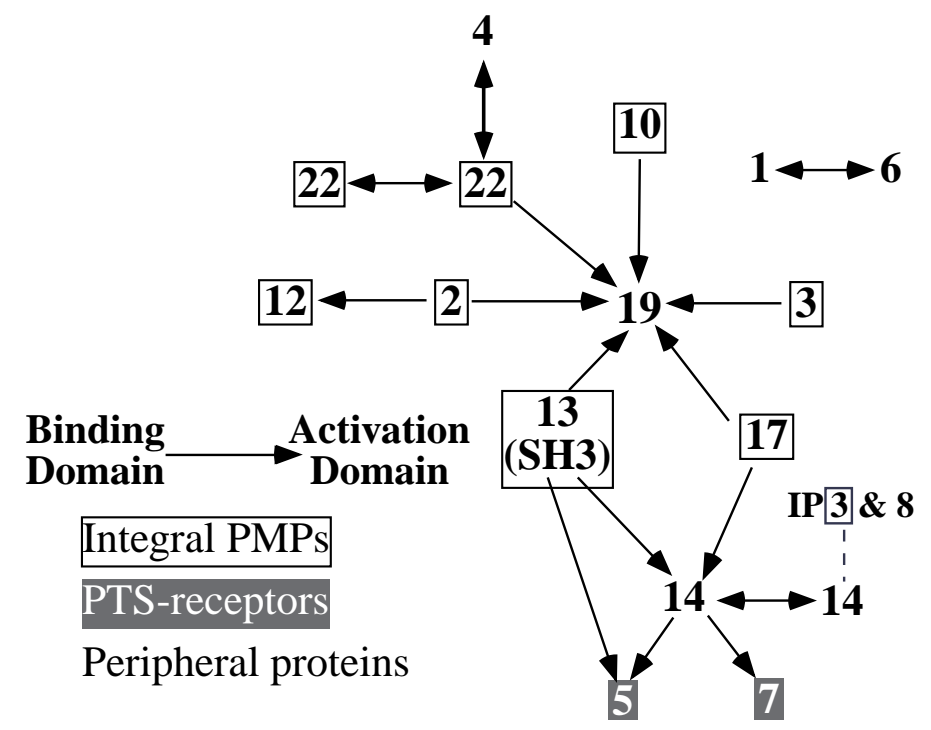

Figure 3 Interactions among peroxins. The interactions are derived from data on P. pastoris, but many of these interactions have also been detected in other systems.

In contrast to the direct binding of Pex 5p to Pex 13p, it is not known whether the interaction between Pex $7 p$ and Pex13p is direct or indirect. These two proteins, Pex $7 p$ and Pex 13p, from Saccharomyces cerevisiae interact in the yeast two-hybrid system in wild-type strains and are found together in coimmunoprecipitates even in the absence of Pex5p and/or Pex14p (32). Furthermore, overexpression of Pex13p suppresses a defective Pex7p. Finally, because Pex13p mutants that fail to interact with Pex $14 p$ can still form a complex with Pex $7 p$, it has been suggested that the N-terminal domain of Pex13p (not the C-terminal SH3 domain) forms a complex with Pex7p (32).

Pex 14p forms complexes with several proteins, such as Pex3p, Pex 5p, Pex 7p, Pex8p, Pex13p, and Pex17p (32,33,39; MA Johnson, WB Snyder, M Veenhuis, S Subramani, J Cregg, unpublished data; Figure 3). These interactions have been detected using the yeast two-hybrid system (32, 33, 37; MA Johnson, WB Snyder, M Veenhuis, S Subramani, J Cregg, unpublished data) and in coimmunoprecipitated complexes $(32,33,39$; MA Johnson, WB Snyder, M Veenhuis, S Subramani, J Cregg, unpublished data). Pex14p appears to be peripherally associated with the peroxisomal membrane in yeasts $(32,33,39$; MA Johnson, WB Snyder, M Veenhuis, S Subramani, J Cregg, unpublished data), although in mammalian cells it behaves as an integral membrane protein $(19,36)$. In S. cerevisiae, in which Pex 14p appears to be a peripheral PMP, it was found (32) that Pex14p was cytosolic in cells lacking Pex13p, suggesting that Pex13p might anchor Pex14p on the peroxisomal membrane, in addition to its other functions. However, the interaction 
between the SH3 domain of Pex13p and the PXXP motif of Pex14p was not necessary for the association of Pex $14 \mathrm{p}$ with the peroxisomal membrane. When this study was published, Pex $14 \mathrm{p}$ was known to interact with only two other PMPs, Pex13p and Pex17p. In light of this information, it seemed surprising that $S$. cerevisiae Pex14p was still associated with the membrane of peroxisome remnants even in pex $13 \Delta /$ pex $17 \Delta$ cells expressing a Pex13p mutant (Pex13p-E320K) that could not interact with Pex14p. However, in view of more recent data showing that Pex14p can also form complexes with other integral PMPs, such as Pex3p, the association of Pex14p with the peroxisomal membrane is likely to be mediated by multiple interactions, such as those with Pex $3 p$, Pex $13 p$, and Pex $17 p$ (39).

Recent experiments in Hansenula polymorpha show that Pex14p is partially phosphorylated on Ser/Thr residues (40). In Pichia pastoris, the phosphorylation of Pex14p has also been demonstrated and appears to regulate the interaction of Pex $14 p$ with certain other peroxins. Pex13p appears to interact only with the phosphorylated form of Pex14p, whereas Pex17p interacts with both forms of Pex14p (MA Johnson, WB Snyder, M Veenhuis, S Subramani, J Cregg, unpublished data). These results suggest that certain interactions between peroxins can be regulated by protein modifications.

Pex $14 p$ is present in a membrane-associated complex with Pex $17 p(32,39,41)$, which appears to be a peripheral membrane protein in $S$. cerevisiae. However, in P. pastoris, Pex17p has a single transmembrane domain and a topology consistent with an N-terminal lumenal domain and a cytosolic C-terminal region (39). The C-terminal domain has two coiled-coil regions of unknown function $(39,41)$, which may mediate interactions with other peroxins containing coiled coils, such as Pex $3 p$ and Pex14p. Although Pex17p is needed for the import of matrix proteins into the peroxisomes and is a component of the peroxisome-associated docking complex, it has recently been shown in P. pastoris that this protein is also required for the efficient import of several PMPs, such as Pex3p and Pex22p, to the peroxisomal membrane. This study shows that Pex $17 \mathrm{p}$ also has a role in the import of at least some, if not all, PMPs, leaving open the possibility that the matrix protein import defect in pex $17 \Delta$ mutants is at least partially a secondary consequence of impaired PMP import (39).

Other PMPs involved in matrix protein import include three zinc-binding ringfinger proteins, Pex2p, Pex10p, and Pex12p (5), as well as Pex15p (42), Pex22p (43), and Pex23p (44). At least one intraperoxisomal protein, Pex8p, is also required for import $(45,46)$. This protein has a PTS1 sequence in $S$. cerevisiae and $P$. pastoris (45) and a PTS2 sequence in $H$. polymorpha (46) and is found in a complex with other peroxins, such as Pex14p (MA Johnson, WB Snyder, M Veenhuis, S Subramani, J Cregg, unpublished data) and Pex5p (46a), but its role in the import of matrix proteins is not yet understood.

Other cytosolic proteins involved in matrix protein import include heat shock proteins of the DnaK (hsp70) (47) and DnaJ (Djp1p) (48) families. The hsp70 protein binds and hydrolyzes ATP, providing at least a partial explanation for the 
ATP requirement during the import of peroxisomal matrix proteins. The precise roles for the heat shock proteins remain a mystery, especially because protein unfolding is not a prerequisite for matrix protein import (49-51). Additionally, Pex18p and Pex21p are related cytosolic proteins that exist in a complex with the PTS2 receptor, Pex 7p, and play a role in the import of PTS2 proteins (52). Because Pex 18p and Pex 21p are related, they may fulfill overlapping functions. Consistent with this view is the observation that deletion of either the PEX18 or the PEX21 gene does not impair PTS2 protein import but deletion of both genes does. Yet another cytosolic protein, Pex20p, interacts with a part of a matrix protein, thiolase, that is outside the PTS2 region and is necessary for the dimerization of thiolase and its import into the peroxisome matrix (53).

Previous studies have revealed that protein unfolding is not obligatory for the transport of polypeptides into the peroxisome matrix $(54,55)$ and that oligomeric proteins can traverse the peroxisomal membrane (49-51). In view of this, one might wonder why the PTS receptors are not transported into the peroxisome matrix. Indeed, there are reports of the occurrence of intraperoxisomal Pex 5p or Pex $7 p$ under certain circumstances $(16,22,23)$. Whether the PTS receptors found in the organelle matrix represent functional or dead-end intermediates in the normal import cycle is an open question. In the majority of reports, however, the PTS receptors are primarily cytosolic $(17,20,24-26,30,56)$. This requires an active mechanism of dissociation of the PTS proteins from their receptors (57) prior to the translocation of the PTS-containing protein across the peroxisomal membrane, but the details of this process are unknown.

Although folded and oligomerized proteins can enter the peroxisome lumen, there is evidence that not all proteins are fully assembled with the necessary cofactors prior to their entry into peroxisomes (58). It has been reported that monomers of alcohol oxidase are imported into peroxisomes of methylotrophic yeasts, where they require the cofactor FAD and an uncharacterized chaperone to form enzymatically active octamers $(59,60)$. These studies have hinted at the existence of intraperoxisomal chaperones. Recently, there was a report of hsp70 existing inside glyoxysomes of watermelons (61). This is an interesting example of a single gene and mRNA apparently generating two proteins by translation from two different initiator AUG codons. Translation from the first AUG yields a longer presequence that targets reporters to the watermelon proplastids. Translation from the second AUG yields a shorter presequence with a PTS2 that is able to function in peroxisomal targeting in $H$. polymorpha. This PTS2 sequence is apparently nonfunctional in the context of the longer presequence (61).

\section{Unanswered Questions Regarding Peroxisomal Matrix Protein Import}

Despite the progress in defining the cytosolic and peroxisome membrane-associated components necessary for the import of matrix proteins, there remain many questions regarding this process. Why do the PTS receptors interact with two 
docking proteins, Pex13p and Pex14p, and do the interactions with the docking proteins occur in a sequential or simultaneous manner? Is the PTS receptor docking complex distinct from the machinery that allows protein translocation across the peroxisomal membrane? What is the nature of the translocation intermediate, and do the proteins traverse a pore or channel as they cross the membrane? How do the PTS receptors catalyze multiple rounds of import? What are the specific ATP-requiring steps in import? What roles do chaperones or factors involved in protein oligomerization or assembly play? What is the function of intraperoxisomal peroxins in matrix protein import?

\section{Import and Assembly of Peroxisomal Membrane Proteins}

For proteins to be imported into the peroxisome matrix, the integral and peripheral PMPs must be present in the peroxisomal membrane; this raises questions regarding the mechanism of assembly of PMPs. These PMPs have distinct targeting signals, called membrane PTSs (mPTSs), that have been defined in several proteins $(42,43,62-64)$ (Figure 1). Unlike the more highly conserved PTSs, the only common feature of mPTSs is a stretch of 6 to 8 basic amino acids $(42,62,64)$. The mPTSs are often oriented topologically on the lumenal side of the peroxisomal membrane, and they may $(42,43)$ or may not $(62-64)$ include an adjacent transmembrane segment.

The pathway of import of PMPs is distinct from the matrix protein import pathways because many pex mutants affect the latter but not the former. Furthermore, in vitro import studies show that peroxisomal matrix and membrane proteins have distinct biochemical characteristics, such as the requirement for ATP for the import of matrix proteins (65-67). The existence of separate pathways for the import of peroxisomal matrix and membrane proteins is a distinguishing feature that sets peroxisomal protein sorting apart from the transport of proteins to other organelles. Because many PMPs are believed to be synthesized in the cytosol and imported posttranslationally from the cytosol directly to the peroxisomal membrane (66-68), there must be mechanisms by which the hydrophobic transmembrane segments on the PMPs are protected and prevented from aggregating in the cytosol. The mechanisms involved in this process are completely unknown.

There are only a few mutations in yeast and mammalian cells that affect PMP import. The pex3 mutant apparently lacks all peroxisome remnants in yeasts $(63,69,70)$. These data place Pex3p at the earliest stages of peroxisome biogenesis, during which time its presence is essential for the formation of detectable peroxisome remnants, which are assumed to be precursors of the mature peroxisomes (Figure 4). However, the mechanism of insertion of Pex3p into the membrane of remnants is not understood. Pex $3 p$ appears to be a protein with a single transmembrane domain, a cytosolic $\mathrm{C}$ terminus, and a lumenal $\mathrm{N}$-terminal segment, the first 40 amino acids of which contain a mPTS $(63,64)$. The cytosolic domain has a putative coiled-coil motif that may be involved in protein-protein interactions with Pex14p and Pex17p. 
Figure 4 Working model for early stages in the biogenesis of peroxisomes, showing the stages at which the three peroxins, Pex3p, Pex17p, and Pex19p, necessary for PMP import and/or assembly act. See text for details.

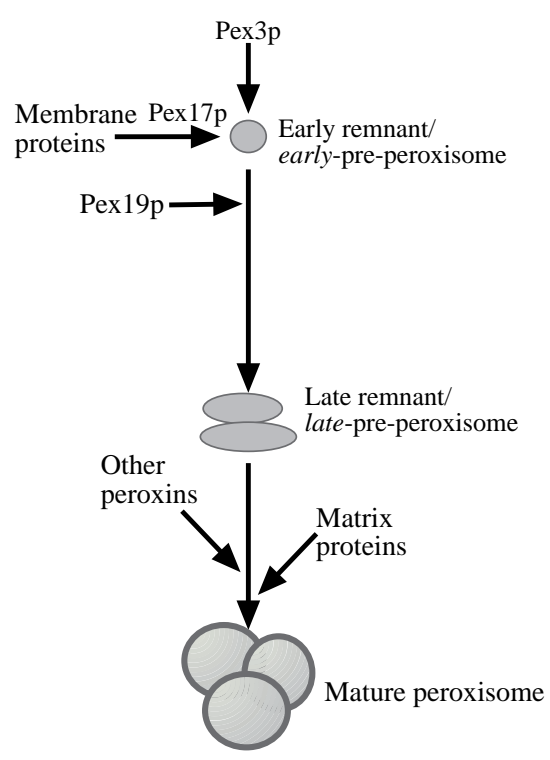

The cytosolic domain of Pex $3 p$ is positioned correctly to interact with a peroxin, Pex19p, which is predominantly cytosolic in most species and only partially peroxisome associated (71-74). In most species, Pex19p is farnesylated at the $\mathrm{C}$ in a C-terminal CAAX motif $(71,73,74)$. However, the farnesylation is not necessary for its functions in P. pastoris (72), nor is it absolutely required in $S$. cerevisiae (71).

In $S$. cerevisiae and in human patient cells lacking the PEX19 gene product, there were no detectable peroxisome remnants $(71,74)$. However, careful analysis of the $P$. pastoris pex $19 \Delta$ cells by deconvolution microscopy has indeed revealed novel vesiculotubular remnants labeled with anti-Pex3p antibodies (72). Thus, targeting of $P$. pastoris Pex $3 p$ to the membranes of the remnants is still possible. Assuming that these Pex3p-containing structures found in the pex19 $\Delta$ mutant are normal intermediates in peroxisome biogenesis, they represent a novel structure called early preperoxisomes, because they are smaller in size than the other "late preperoxisomes" that accumulate as remnants in most other pex mutants. This places one of the sites of action of Pex19p at the early preperoxisome membrane, where its interaction with Pex3p presumably occurs and is necessary for the conversion of early preperoxisomes to late preperoxisomes (Figure 4). We use the term preperoxisome to refer to intermediates committed to becoming peroxisomes, and not other organelles, in wild-type cells.

An important clue to the possible function of Pex19p is that it interacts with many other PMPs in both yeast and mammalian cells (Figure 3) (39, 72; K Sacksteder, J Jones, SJ Gould, personal communication). In P. pastoris, it interacts 
with the PMPs Pex2p, Pex3p, Pex10p, Pex13p, Pex17p, and Pex22p (39, 72). By analogy to the PTS receptors Pex $5 p$ and Pex $7 p$, which are mainly cytosolic and partially peroxisome associated, it seems plausible that Pex19p shuttles PMPs from their site of synthesis in the cytosol to the peroxisome membrane. This hypothesis suggests that Pex19p might be the mPTS receptor. Preliminary results indicate that Pex19p interacts with the cytosolic domains of several PMPs (such as Pex3p, Pex13p, and Pex22p) rather than with the lumenal mPTSs (72; WB Snyder, A Koller, S Subramani, unpublished data). These results make it more likely that Pex19p is not the mPTS receptor but rather is an assembly factor for PMPs, facilitating the conversion of early to late preperoxisome intermediates. However, it remains to be proven whether Pex19 interacts with its partners in the cytosol or at the peroxisome membrane in vivo.

There is a qualitative difference between the interaction of Pex19p with Pex3p and its interaction with other PMPs. The N-terminal segment of Pex 19p interacts with the C-terminal, cytosolic segment of Pex3p. In contrast, the interaction of Pex 19p with many other peroxins, such as Pex10p and Pex17p, occurs via its C-terminal domain $(39,72)$. Although more detailed mapping of the interaction domains is certainly necessary, this suggests that the role of the Pex19p/Pex3p interaction may be distinct from the interaction of Pex 19p with other PMPs. One possibility, consistent with these data and the requirement of Pex $3 p$ for the earliest stages of peroxisome biogenesis, is that Pex $3 p$ is the docking protein on the peroxisome membrane for Pex19p. Once Pex19p is associated with the peroxisome membrane in this manner, it could then interact with the other PMPs via a different domain, as a chaperone or assembly factor, to facilitate their assembly during the conversion of early preperoxisome intermediates to the late preperoxisomes (Figure 4).

A third component in the biogenesis of PMPs is Pex17p, which was described earlier as a subunit of the matrix protein import complex in S. cerevisiae (41). In $P$. pastoris, mutants lacking Pex17p are partially defective in the import of several PMPs (Pex3p, Pex22p, and Pex10p) to remnant-like structures (39). Pex17p forms complexes with Pex3p, Pex14p, and Pex19p, and exists in several distinct subcomplexes (or conformational states, as detected by accessibility to crosslinkers) involving Pex17p (39). The presence of Pex3p in immunoprecipitates with either Pex 14p or Pex 17p had not been detected earlier in $S$. cerevisiae because most of the complexes were studied after immunoprecipitation of $\operatorname{Pex} 7 \mathrm{p}(32,41)$. There are separable pools of Pex3p in complexes with Pex14p, Pex17p, and Pex19p and of Pex17p in complexes with Pex14p and Pex19p. Similarly, there appear to be separable pools of Pex17p in association with either Pex5p-Pex7p, Pex3p, or Pex19p (39).

It is interesting that, in the absence of Pex 19p, several other PMPs, such as Pex3p and Pex22p, are in the membranes of remnants (72; WB Snyder, S Subramani, unpublished data). Thus, Pex19p is not involved directly in the insertion of PMPs in the membrane but rather participates in a step after membrane association. In contrast, Pex17p has a function as an assembly factor before membrane insertion 
of PMPs, because in its absence several PMPs remain partially cytosolic (39; Figure 4). It remains to be seen whether Pex 17p also has a role in PMP assembly after its own association with the membrane.

A fourth component, Pex16p, has been implicated in PMP import. The Yarrowia lipolytica pex16 16 mutants are partially deficient in the import of a PMP, Pex $2 p$ (75). Unfortunately, the import of other PMPs has not been analyzed in this strain. The pex $16 \Delta$ mutant is also impaired in the import of some matrix proteins, such as isocitrate lyase, thiolase, and catalase, but not others (acyl-CoA oxidase and proteins recognized by an anti-SKL peptide antibody). In Y. lipolytica strains lacking functional Pex $16 \mathrm{p}$, there is an accumulation of clustered vesicular structures that are 40 to $50 \mathrm{~nm}$ in diameter, and occasionally larger ones (100 to $150 \mathrm{~nm}$ in diameter), that are labeled for peroxisomal markers, suggesting that they are remnants.

A human cell line from a Zellweger syndrome patient was mutated in human PEX16 (76). In this cell line, no detectable peroxisome remnants were detected by indirect immunofluorescence, but it should be noted that small, vesicular remnants might have escaped detection by this technique. Notably, several PMPs (PMP70, PEX12-myc, PMP32-myc, ALDP, P70R, PEX3-myc, PEX10-myc, PEX11 $\alpha$-myc, and PEX13-myc) are not imported into normal peroxisomes in the human PEX16deficient lines. However, it remains uncertain whether these unimported PMPs are truly cytosolic or are associated with small remnants that are beyond the resolution limit of conventional light microscopy. As noted above, such remnants have been found in Y. lipolytica mutants lacking Pex16p.

Although no remnants were detected in the PEX16-deficient cells, transfection or microinjection of these cells with the PEX16 cDNA resulted in the restoration of normal peroxisomes. Interestingly, a temporal analysis of the accumulation of various matrix and membrane markers in cells microinjected with the cDNA encoding PEX16-myc revealed that the import of PEX16-myc into punctate structures preceded the import of PMP70 and that the import of catalase occurred later (76). These data are consistent with a model in which PEX16 accumulates first in nascent preperoxisomes (arising from uncharacterized and perhaps uncommitted precursor membranes), allowing the efficient import of other specific PMPs. The exact relationship of these hypothetical, mammalian precursor membranes and of the nascent preperoxisomes to the early and late preperoxisomes observed in yeasts (72) is not clear at present. We do not know at present whether the two other peroxins involved in PMP insertion into membranes, PEX3 and PEX17, are incorporated into the membranes of uncommitted precursor membranes or nascent preperoxisomes before, during, or after PEX16. In yeasts, once the early preperoxisome is assembled, the action of Pex19p and its interactions with multiple PMPs would rearrange or assemble the PMPs in the membranes of the early preperoxisomes to allow their maturation to late preperoxisomes. These late preperoxisomes accumulate as late remnants in several mutants lacking some component of the matrix protein import machinery. When this machinery is functional, import of PTS1and PTS2-containing proteins would allow the conversion of late preperoxisomes to mature peroxisomes. 
This outline of a pathway for peroxisome assembly is no doubt oversimplified, and there probably coexists a pathway in which peroxisomes arise by fission and growth of preexisting peroxisomes (76). Proteins such as PEX11 $\alpha$ and PEX11 $\beta$ play a role in peroxisome fission or division in yeast and in mammalian cells (77). Not surprisingly, overproduction of Pex11p leads to the accumulation of smaller-than-normal peroxisomes, while cells lacking Pex11p have fewer giant peroxisomes (78).

\section{Unanswered Questions Regarding PMP Biogenesis}

Our knowledge of the mechanisms involved in the insertion of PMPs into the peroxisomal membrane is still quite fragmented and incomplete. For the PMPs that are synthesized in the cytosol and then imported into the peroxisomal membrane, how are the hydrophobic transmembrane segments sequestered and prevented from aggregating? What is the mPTS receptor, and how does it function? Are PMPs inserted into the peroxisomal membrane in the unfolded state, and, if so, how do they fold and assemble into complexes in the membrane? Do PMPs use the same translocon as do matrix proteins in the peroxisomal membrane? Do the peroxins implicated in PMP import and/or assembly act in the cytosol on newly synthesized proteins or at the peroxisome membrane? Finally, does the posttranslational import of PMPs directly from the cytosol to the peroxisome membrane hold for all PMPs?

\section{Is There a Quality Control Pathway for Peroxisomal Membrane Proteins?}

One of the peroxins, Pex4p, is a ubiquitin-conjugating enzyme (UBC) that is conserved in several yeasts (79-81) and can be found conjugated to ubiquitin tagged with a myc epitope (80).

It is known from other systems that polyubiquitination of proteins targets them for proteolysis by the $26 \mathrm{~S}$ proteasome $(82,83)$. In contrast, monoubiquitination is involved in endocytosis $(84,85)$ and in protein-targeting events $(86)$. However, there is no previous precedent for a role for ubiquitination in the biogenesis of any organelle other than the peroxisome.

The substrate for Pex4p-mediated ubiquitination is not known. Consequently, we do not know what type of ubiquitination is involved. Pex $4 \mathrm{p}$ is a peripheral PMP that must be held at the membrane via interactions with some other macromolecule. This has been shown to be another peroxin, Pex22p, which is an integral PMP whose $\mathrm{N}$ terminus is in the peroxisome lumen and whose $\mathrm{C}$ terminus is in the cytosol (43). It is this C-terminal, cytosolic domain that interacts with Pex4p and anchors it on the membrane. There appears to be no detectable ubiquitination of Pex 22p, so it is not the substrate for Pex4p.

A striking phenotype of both the pex $4 \Delta$ and the pex $22 \Delta$ strains is Pex $5 p$ instability $(43,81)$. This instability of the PTS1 receptor does not extend to Pex $7 p$, the PTS2 receptor, and therefore cannot be the sole explanation for the impairment of the PTS1 and PTS2 matrix import pathways (43). Supporting this is the fact that, 
in . pastoris, overexpression of Pex5p does not suppress the PTS1 protein import defect (43), although in $H$. polymorpha such suppression has indeed been reported (81). The instability of Pex5p in the pex $4 \Delta$ and the pex $22 \Delta$ strains is not likely to be caused by the failure of cytosolic Pex $5 \mathrm{p}$ to dock at the peroxisomal membrane, because in other such mutants (pex13 $\Delta$ ) cytosolic Pex 5p is not turned over. It will be interesting to see whether it is the failure of cargo-bound Pex $5 p$ to recycle for another round of import that causes its instability in the absence of Pex $4 \mathrm{p}$.

The role of Pex $22 p$ in anchoring the UBC Pex $4 p$ on the peroxisomal membrane is analogous to the anchoring of $\mathrm{Ubc} 7 \mathrm{p}$ on the cytosolic side of the endoplasmic reticulum membrane by interaction with the integral membrane protein Cue1p $(87,88)$. Both Cue1p and Ubc7p (as well as Ubc6p) are involved in the quality control of misfolded proteins entering the endoplasmic reticulum membrane or lumen. By analogy, it has been suggested that Pex4p may regulate the assembly or stoichiometry of PMP complexes either directly or indirectly (43; Figure 5). If the action of Pex $4 p$ is to ubiquitinate misfolded or nonstoichiometric PMPs and target them for degradation, then in the absence of Pex4p these PMPs would accumulate and inhibit peroxisome biogenesis. Indeed, overexpression of several PMPs, such as Pex3p and Pex14p, is known to cause a Pex phenotype $(40,89,90)$. An alternative possibility is that Pex $4 p$ negatively regulates (by ubiquitination and

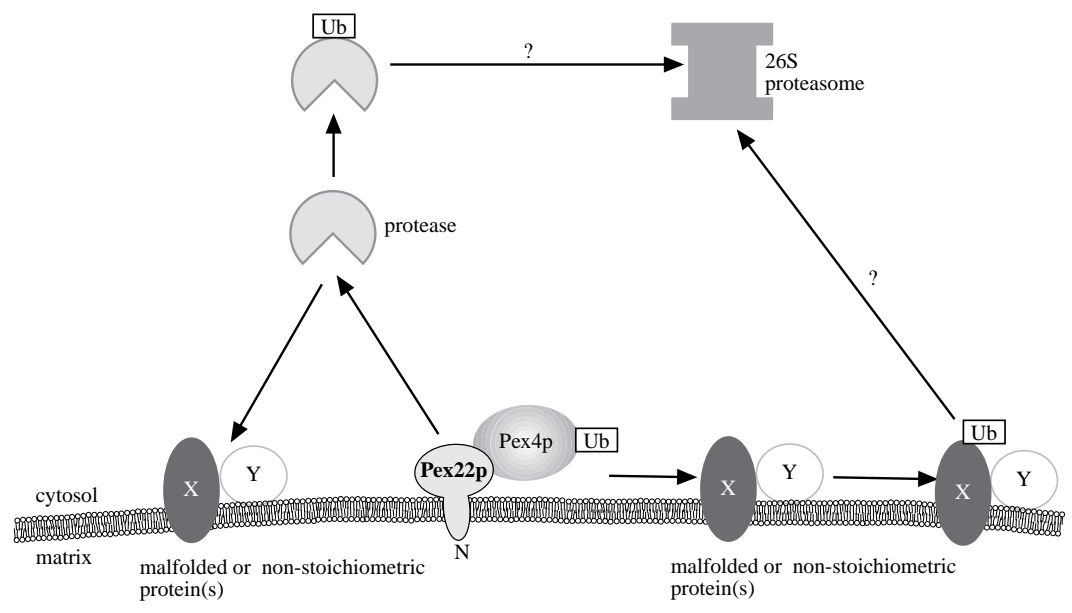

Figure 5 Working model for the putative roles of Pex $4 p$ and Pex $22 p$ in quality control of peroxisomal membrane proteins. Two possible scenarios are depicted. One possibility, shown on the right, is that malfolded or nonstoichiometric PMPs (X/Y) may be ubiquitinated by the UBC Pex4p, which is held on the peroxisomal membrane by association with Pex22p. The ubiquitination (Ub) of the protein $\mathrm{X}$ might target it for degradation by the $26 \mathrm{~S}$ proteasome. The alternative possibility, shown on the left, is that the malfolded or nonstoichiometric proteins $(\mathrm{X} / \mathrm{Y})$ may be degraded by a protease whose activity is kept in check by Pex4p-mediated ubiquitination. The protease modified by ubiquitin might then be a degradation target for the proteasome. 
targeting to the proteasome) a protease that modulates the assembly of import complexes. In the absence of Pex4p, such a protease would be overactive and, consequently, would inhibit peroxisome biogenesis (43). This would also explain the instability of Pex5p in pex $4 \Delta$ or pex $22 \Delta$ strains. Clearly, the discovery of the substrate for Pex $4 p$ and the modification catalyzed by the UBC will help in uncovering the role of this peroxin.

\section{Interactions Among Peroxins}

One of the most significant advances made in the field in the last few years has been the elucidation of the network of interactions between peroxins (Figure 3). Much of this progress has come from the use of the yeast two-hybrid method, by which sets of peroxins have been tested for interactions in pairwise combinations (30, 32, 33, 37, 39, 41, 43, 52, 71, 72, 91; MA Johnson, WB Snyder, M Veenhuis, S Subramani, J Cregg, unpublished data). When such experiments have been done in the homologous yeast (i.e. the analysis of $S$. cerevisiae genes in $S$. cerevisiae), some interactions revealed in the two-hybrid system have been found to be indirectly bridged by an endogenous cellular protein. For example, the interactions between $S$. cerevisiae Pex5p and $S$. cerevisiae Pex 17p, as well as that between $S$. cerevisiae Pex $5 \mathrm{p}$ and $S$. cerevisiae Pex $7 \mathrm{p}$, were found to be bridged by $S$. cerevisiae Pex $14 \mathrm{p}$, and the interactions were lost when the two-hybrid analysis was done in a pex $14 \Delta$ strain $(32,41)$. In other instances, certain interactions may have been masked by competition with endogenous proteins but were easily detected by the use of heterologous proteins, as illustrated by the interaction between $P$. pastoris Pex19p and P. pastoris Pex10p (72).

The results obtained using the yeast two-hybrid system have often been confirmed by the use of coimmunoprecipitation techniques, and occasionally ligand blot analyses that are aimed at studying binding interactions between partner proteins (19). The use of cleavable cross-linkers has aided the detection of interactions that may have been transient or unstable $(39,72)$. The network of interactions revealed by these studies is shown in Figure 3.

It is striking that two peroxins, in particular, stand out in their ability to form complexes with at least half a dozen proteins. Pex $14 p$ forms complexes with Pex $3 p$, Pex5p, Pex7p, Pex8p, Pex13p, Pex17p, and itself (MA Johnson, WB Snyder, M Veenhuis, S Subramani, J Cregg, unpublished data), and Pex19p forms complexes with many integral PMPs, such as Pex2p, Pex3p, Pex10p, Pex12p, Pex13p, Pex17p, and Pex22p (39; WB Snyder, A Koller, S Subramani, unpublished data). How these proteins interact with so many different partners is an interesting structural problem. Evidence for the existence of multiple, dynamic subcomplexes of peroxins is also accumulating, and it is likely that they play important roles in import (39).

Another important insight that has emerged from the study of these complexes is that certain peroxins involved primarily in matrix protein import (e.g., Pex13p and Pex 14p) and others involved mostly in PMP (and therefore also matrix protein) 
import (e.g., Pex3p and Pex 17p) are found together in complexes (39). This suggests that certain peroxins, such as Pex $3 p$ and Pex $17 p$, may play a role in the coordination of peroxisomal matrix and membrane protein assembly.

Finally, the existence of so many interactions among peroxins and the identification of many subcomplexes suggest that the ordered assembly and disassembly of these complexes must be orchestrated. In this context, it is easy to understand why the overexpression of certain membrane-bound peroxins results in an importdeficient phenotype $(40,89,90)$. These results also stress the importance of putative factors that facilitate the assembly of PMP complexes, as well as of quality-control factors.

\section{HUMAN PEROXISOMAL DISEASES}

\section{Disorders Caused by Peroxin Mutations}

The appreciation that the peroxisome is the subcellular organelle affected (92) in patients with the Zellweger cerebrohepatorenal syndrome (93) focussed attention on the role of this organelle in human disease. Since that time, clinicians have defined at least 16 human disorders connected with either peroxisomal metabolic pathways or peroxisome biogenesis, or both. These diseases, their symptoms, and their prevalence have been reviewed elsewhere (94). All of the disorders are recessive, and with one exception (X-linked adrenoleukodystrophy) they are autosomal. Although most of the patients afflicted with these disorders eventually die, their cells can be propagated in the laboratory and examined for peroxisome-associated defects.

The molecular basis of the disorders affecting peroxisomal metabolism directly can be explained simply by the occurrence of single-gene mutations that compromise either the activity or subcellular localization of a single protein. In contrast, clues to the understanding of the pleiotropic effects of peroxisome biogenesis disorders (PBDs) such as Zellweger syndrome, neonatal adrenoleukodystrophy, and infantile Refsum disease came only in the late 1980s, when it was discovered that cells from these patients mislocalized multiple peroxisomal matrix proteins in the cytosol but targeted membrane proteins to structures termed peroxisome "ghosts" (95). These experiments pointed to the possibility that protein import defects might cause these disorders. Evidence supporting this hypothesis came later, when Walton et al (96) showed that, while normal human fibroblasts imported microinjected peroxisomal matrix proteins into the organelle lumen, fibroblasts from patients with such disorders did not. These observations were extended to cells from other complementation groups (97-99).

The recognition of protein import defects in the human PBDs, coupled with the use of genetic strategies for the generation of pex mutants of $\mathrm{CHO}$ cells, allowed the use of functional complementation for the isolation of the first mammalian PEX gene (PEX2) (100). The connection of this gene to a human PBD came soon thereafter (101). 
TABLE 1 Conserved $P E X$ genes and their role in human peroxisome biogenesis disorders

\begin{tabular}{llllll}
\hline & & \multicolumn{3}{c}{ Classification $^{\text {a }}$} & \\
\cline { 3 - 5 } Gene & Group (2) & Gifu & KKI & AMC & Reference(s) \\
\hline PEX1 & $\langle 5\rangle$ & $\langle\mathrm{E}\rangle$ & $\langle 1\rangle$ & $\langle\mathrm{II}\rangle$ & $\langle 105-107\rangle$ \\
PEX2 & $\langle 6\rangle$ & $\langle\mathrm{F}\rangle$ & $\langle 10\rangle$ & $\langle\mathrm{V}\rangle$ & $\langle 100,101\rangle$ \\
PEX5 & $\langle 10\rangle$ & - & $\langle 2\rangle$ & $\langle\mathrm{IV}\rangle$ & $\langle 17,20,108\rangle$ \\
PEX6 & $\langle 3\rangle$ & $\langle\mathrm{C}\rangle$ & $\langle 4\rangle$ & $\langle\mathrm{III}\rangle$ & $\langle 109,110\rangle$ \\
PEX7 & $\langle 13\rangle$ & $\langle\mathrm{R}\rangle$ & $\langle 11\rangle$ & $\langle\mathrm{I}\rangle$ & $\langle 26-28\rangle$ \\
PEX10 & $\langle 2\rangle$ & $\langle\mathrm{B}\rangle$ & $\langle 7 / 5\rangle$ & - & $\langle 111,112\rangle$ \\
PEX12 & $\langle 11\rangle$ & - & $\langle 3\rangle$ & - & $\langle 113,114\rangle$ \\
PEX13 & $\langle 8\rangle$ & $\langle\mathrm{H}\rangle$ & - & - & $\langle 115,116\rangle$ \\
PEX16 & $\langle 4\rangle$ & $\langle\mathrm{D}\rangle$ & $\langle 9\rangle$ & - & $\langle 76,117\rangle$ \\
PEX19 & $\langle 9\rangle$ & $\langle\mathrm{J}\rangle$ & - & - & $\langle 74\rangle$ \\
\hline
\end{tabular}

${ }^{\mathrm{a}}$ Gifu, Gifu University, Japan; KKI, Kennedy Krieger Institute, Baltimore, MD; AMC, Academic Medical Center, Amsterdam, The Netherlands.

In the period since 1992, the confluence of three sets of discoveries has led to significant breakthroughs for the human PBDs. First, the use of genetically manipulable organisms, such as yeasts, led to the isolation of numerous pex mutants and to the characterization of 23 PEX genes. Second, the genome sequencing efforts and sequence alignment programs enabled the search for homologs in higher eukaryotes (102). Third, the remarkable conservation of the mechanism of peroxisome biogenesis led to the identification of many mammalian PEX genes, supplanting the more cumbersome functional complementation strategy (100). These advances have led in just 7 years to the discovery that at least 13 of 23 PEX genes are conserved in humans. More impressive is the fact that 10 of 13 human $P E X$ genes are implicated in the human PBDs (Table 1). Human homologs have been described for three other PEX genes, PEX3, PEX11, and PEX14, but these have not yet been connected to human disease $(36,64,77,103,104)$. There are few areas of biology in which so many disease genes have been defined so rapidly, primarily based on conservation of a biological process. It should be comforting to patients and clinicians that the molecular basis of most of the human PBDs will be understood soon.

\section{Disorders Resulting from Mutations in Proteins Other Than Peroxins}

Phenomenal progress has also been made in the elucidation of the molecular basis of other disorders in which peroxisomal enzymes, and not PEX genes, are affected (Table 2). Many of these diseases are caused by deficiencies in lipid 
TABLE 2 Peroxisomal disorders caused by proteins that are not peroxins ${ }^{a}$

\begin{tabular}{lll}
\hline Disease & Affected protein & Reference \\
\hline $\begin{array}{l}\text { X-linked adrenoleukodystrophy (ALD) } \\
\text { Malonyl-CoA carboxylase (MCD) }\end{array}$ & $\langle$ ALD protein (ALDP) $\rangle$ & $\langle 118\rangle$ \\
deficiency & $\langle$ MCD $\rangle$ & \\
Mevalonic aciduria & $\langle$ Mevalonate kinase $\rangle$ & $\langle 119\rangle$ \\
Glutaric aciduria type 3 & $\langle$ Glutaryl-CoA oxidase $\rangle$ & $\langle 120\rangle$ \\
Hyperoxaluria type 1 & $\langle$ Alanine-glyoxylate amino & $\langle 2\rangle$ \\
& transferase $\rangle$ & \\
D-Bifunctional protein deficiency & $\langle$ Enoyl-CoA hydratase domain & \\
& of D-bifunctional enzyme $\rangle$ & $\langle 122\rangle$ \\
$\beta$-Oxidation deficiency & $\langle$ D-Bifunctional enzyme $\rangle$ & $\langle 123\rangle$ \\
Refsum disease & $\langle$ Phytanoyl-CoA hydroxylase $\rangle$ & $\langle 124\rangle$ \\
Rhizomelic chondrodysplasia & $\langle$ Acyl-CoA dihydroxyacetone- & \\
punctata (RCDP) type 2 & phosphate (DHAP) acyl-transferase $\rangle$ & $\langle 125\rangle$ \\
RCDP type 3 & $\langle$ AlkyIDHAP synthase $\rangle$ & $\langle 126\rangle$ \\
Acatalasemia & $\langle$ Catalase $\rangle$ & $\langle 127\rangle$ \\
Acyl-CoA oxidase deficiency & $\langle$ Acyl-CoA oxidase $\rangle$ & $\langle 128\rangle$ \\
Peroxisomal thiolase deficiency & $\langle$ Peroxisomal thiolase $\rangle$ & $\langle 129\rangle$ \\
\hline
\end{tabular}

${ }^{\mathrm{a}}$ Adapted from reference 2 .

metabolism, and this has led to a much greater appreciation and interest in the metabolic pathways that reside in peroxisomes.

\section{ACKNOWLEDGMENTS}

This work was supported by grants to S. S. from the March of Dimes Birth Defects Foundation and the NIH (DK41737).

Additional information on peroxins can be found at http://www.biology.ucsd.edu/ labs/subramani/

\section{Visit the Annual Reviews home page at www.AnnualReviews.org}

\section{LITERATURE CITED}

1. van den Bosch H, Schutgens RBH, Wanders RJA, Tager JM. 1992. Annu. Rev. Biochem. 61:157-97

2. Wanders RJA. 1999. Neurochem. Res. 24: 565-80

3. Elgersma Y, Tabak HF. 1996. Biochim. Biophys. Acta 1286:269-83
4. Kunau WH. 1998. Curr. Opin. Microbiol. 1:232-37

5. Subramani S. 1998. Physiol. Rev. 78:171-88

6. Olsen LJ. 1998. Plant Mol. Biol. 38:16389

7. Crookes WJ, Olsen LJ. 1999. Naturwissenschaften 86:51-61 
8. Fujiki Y. 1997. Biochim. Biophys. Acta 1361:235-50

9. Subramani S. 1996. J. Biol. Chem. 271: 32483-86

10. Kunau WH, Erdmann R. 1998. Curr. Biol. 8:R299-R302

11. Titorenko VI, Rachubinski RA. 1998. Trends Biochem. Sci. 23:231-33

12. Yuan W, Stromhaug PE, Dunn WA Jr. 1999. Mol. Biol. Cell 10: 1353-66

13. McCollum D, Monosov E, Subramani S. 1993. J. Cell Biol. 121:761-74

14. Van der Leij I, Franse MM, Elgersma Y, Distel B, Tabak HF. 1993. Proc. Natl. Acad. Sci. USA 90:11782-86

15. Terlecky SR, Nuttley WM, McCollum D, Sock E, Subramani S. 1995. EMBO J. 14: 3627-34

16. Szilard RK, Titorenko VI, Veenhuis M, Rachubinski RA. 1995. J. Cell Biol. 131: 1453-69

17. Dodt G, Braverman N, Wong C, Moser A, Moser HW, et al. 1995. Nat. Genet. 9: $115-25$

18. Dodt G, Gould SJ. 1996. J. Cell Biol. 135: 1763-74

19. Fransen M, Terlecky SR, Subramani S. 1998. Proc. Natl. Acad. Sci. USA 95:808792

20. Wiemer EA, Nuttley WM, Bertolaet BL, Li X, Francke U, et al. 1995. J. Cell Biol. 130:51-65

21. Marzioch M, Erdmann R, Veenhuis M, Kunau WH. 1994. EMBO J. 13:490818

22. Zhang JW, Lazarow PB. 1995. J. Cell Biol. 129:65-80

23. Zhang JW, Lazarow PB. 1996. J. Cell Biol. 132:325-34

24. Rehling P, Marzioch M, Niesen F, Wittke E, Veenhuis M, et al. 1996. EMBO J. 15: 2901-13

25. Elgersma $\mathrm{Y}$, Elgersma-Hooisma $\mathrm{M}$, Wenzel T, McCaffery JM, Farquhar MG, et al. 1998. J. Cell Biol. 140:807-20

26. Braverman N, Steel G, Obie C, Moser A, Moser H, et al. 1997. Nat. Genet. 15:36976
27. Purdue PE, Zhang JW, Skoneczny M, Lazarow PB. 1997. Nat. Genet. 15:381-84

28. Motley AM, Hettema EH, Hogenhout EM, Brites P, ten Asbroek AL, et al. 1997. Nat. Genet. 15:377-80

29. Erdmann R, Blobel G. 1996. J. Cell Biol. 135:111-21

30. Elgersma Y, Kwast L, Klein A, VoornBrouwer T, van den Berg M, et al. 1996. J. Cell Biol. 135: 97-109

31. Gould SJ, Kalish JE, Morrell JC, Bjorkman J, Urquhart AJ, et al. 1996. J. Cell Biol. 135:85-95

32. Girzalsky W, Rehling P, Stein K, Kipper J, Blank L, et al. 1999. J. Cell Biol. 144:115162

33. Albertini M, Rehling P, Erdmann R, Girzalsky W, Kiel JA, et al. 1997. Cell 89:8392

34. Will GK, Soukupova M, Hong X, Erdmann KS, Kiel JA, et al. 1999. Mol. Cell. Biol. 19:2265-77

35. Schliebs W, Saidowsky J, Agianian B, Dodt G, Herberg FW, et al. 1999. J. Biol. Chem. 274:5666-73

36. Shimizu N, Itoh $\mathrm{R}$, Hirono $\mathrm{Y}$, Otera $\mathrm{H}$, Ghaedi K, et al. 1999. J. Biol. Chem. 274: 12593-604

37. Brocard C, Lametschwandtner G, Koudelka R, Hartig A. 1997. EMBO J. 16:5491-500

38. Mongiovi AM, Romano P, Panni S, Mendoza M, Wong WT, et al. 1999. EMBO J. 18:5300-09

39. Snyder WB, Koller A, Choy AJ, Johnson MA, Cregg JM, et al. 1999. Mol. Biol. Cell 10:4005-19

40. Komori M, Kiel JA, Veenhuis M. 1999. FEBS Lett. 457:397-99

41. Huhse B, Rehling P, Albertini M, Blank L, Meller K, et al. 1998. J. Cell Biol. 140: 49-60

42. Elgersma Y, Kwast L, van den Berg M, Snyder WB, Distel B, et al. 1997. EMBO J. 16:7326-41

43. Koller A, Snyder WB, Faber KN, Wenzel TJ, Rangell L, et al. 1999. J. Cell Biol. 146: 99-112 
44. Brown TW, Titorenko VI, Rachubinski RA. 2000. Mol. Biol. Cell. 11:141-52

45. Liu H, Tan XQ, Russell KA, Veenhuis M, Cregg JM. 1995. J. Biol. Chem. 270: 10940-51

46. Waterham HR, Titorenko VI, Haima P, Cregg JM, Harder W, et al. 1994. J. Cell Biol. 127:737-49

46a. Rehling P, Skaletz-Rorowski A, Girzalsky W, Voorn-Brouwer T, Franse MM, et al. 2000. J. Biol. Chem. 275:3593-602

47. Walton PA, Wendland M, Subramani S, Rachubinski RA, Welch WJ. 1994. J. Cell Biol. 125:1037-46

48. Hettema EH, Ruigrok CCM, Koerkamp MG, van den Berg M, Tabak HF, et al. 1998. J. Cell Biol. 142:421-34

49. Glover JR, Andrews DW, Rachubinski RA. 1994. Proc. Natl. Acad. Sci. USA 91: 10541-45

50. McNew JA, Goodman JM. 1994. J. Cell Biol. 127:1245-57

51. Lee MS, Mullen RT, Trelease RN. 1997. Plant Cell 9:185-97

52. Purdue PE, Yang XD, Lazarow PB. 1998. J. Cell Biol. 143:1859-69

53. Titorenko VI, Smith JJ, Szilard RK, Rachubinski RA. 1998. J. Cell Biol. 142: 403-20

54. Walton PA, Hill PE, Subramani S. 1995. Mol. Biol. Cell 6:675-83

55. Hausler T, Stierhof Y-D, Wirtz E, Clayton C. 1996. J. Cell Biol. 132:311-24

56. Wimmer C, Schmid M, Veenhuis M, Gietl C. 1998. Plant J. 16:453-64

57. Rachubinski RA, Subramani S. 1995. Cell 83:525-28

58. Bellion E, Goodman JM. 1987. Cell 48: 165-73

59. Evers ME, Titorenko VI, van der Klei IJ, Harder W, Veenhuis M. 1994. Mol. Biol. Cell 5:829-37

60. Evers ME, Titorenko V, Harder W, van der Klei IJ, Veenhuis M. 1996. Yeast 12:91723

61. Wimmer B, Lottspeich F, van der Klei I, Veenhuis M, Gietl C. 1997. Proc. Natl. Acad. Sci. USA 94:13624-29
62. McCammon MT, McNew JA, Willy PJ, Goodman JM. 1994. J. Cell Biol. 124: 915-25

63. Wiemer EAC, Luers G, Faber KN, Wenzel T, Veenhuis M, et al. 1996. J. Biol. Chem. 271:18973-80

64. Kammerer S, Holzinger A, Welsch U, Roscher AA. 1998. FEBS Lett. 429:5360

65. Small GM, Szabo LJ, Lazarow PB. 1988. EMBO J. 7:1167-73

66. Diestelkotter P, Just WW. 1993. J. Cell Biol. 123:1717-25

67. Imanaka T, Shiina Y, Takano T, Hashimoto T, Osumi T. 1996. J. Biol. Chem. 271: 3706-13

68. Lazarow PB, Fujiki Y. 1985. Annu. Rev. Cell Biol. 1:489-530

69. Hohfeld J, Veenhuis M, Kunau WH. 1991. J. Cell Biol. 114:1167-78

70. Baerends RJS, Rasmussen SW, Hilbrands RE, van der Heide M, Faber KN, et al. 1996. J. Biol. Chem. 271:8887-94

71. Gotte K, Girzalsky W, Linkert M, Baumgart E, Kammerer S, et al. 1998. Mol. Cell. Biol. 18:616-28

72. Snyder WB, Faber KN, Wenzel TJ, Koller A, Luers GH, et al. 1999. Mol. Biol. Cell 10:1745-61

73. James GL, Goldstein JL, Pathak RK, Anderson RG, Brown MS. 1994. J. Biol. Chem. 269:14182-90

74. Matsuzono Y, Kinoshita N, Tamura S, Shimozawa N, Hamasaki M, et al. 1999. Proc. Natl. Acad. Sci. USA 96:2116-21

75. Eitzen GA, Szilard RK, Rachubinski RA. 1997. J. Cell Biol. 137:1265-78

76. South ST, Gould SJ. 1999. J. Cell Biol. 144:255-66

77. Schrader M, Reuber BE, Morrell JC, Jimenez SG, Obie C, et al. 1998. J. Biol. Chem. 273:29607-14

78. Marshall PA, Dyer JM, Quick ME, Goodman JM. 1996. J. Cell Biol. 135:123-37

79. Wiebel FF, Kunau WH. 1992. Nature 359:73-76

80. Crane DI, Kalish JE, Gould SJ. 1994. J. Biol. Chem. 269:21835-44 
81. van der Klei IJ, Hilbrands RE, Kiel JA, Rasmussen SW, Cregg JM, et al. 1998. EMBO J. 17:3608-18

82. Ciechanover A. 1994. Biol. Chem. Hoppe Seyler 375:565-81

83. Smith SE, Koegl M, Jentsch S. 1996. Biol. Chem. 377:437-46

84. Kolling R, Hollenberg CP. 1994. EMBO J. 13:3261-71

85. Strous GJ, van Kerkhof $P$, Govers R, Ciechanover A, Schwartz AL. 1996. EMBO J. 15:3806-12

86. Zhaung ZP, McCauley R. 1989. J. Biol. Chem. 264:14594-96

87. Biederer T, Volkwein C, Sommer T. 1997. Science 278:1806-9

88. Sommer T, Wolf DH. 1997. FASEB J. 11:1227-33

89. Baerends RJ, Salomons FA, Kiel JA, van der Klei IJ, Veenhuis M. 1997. Yeast 13: 1449-63

90. Baerends RJ, Salomons FA, Faber KN, Kiel JA, van der Klei IJ, et al. 1997. Yeast 13:1437-48

91. Faber KN, Heyman JA, Subramani S. 1998. Mol. Cell. Biol. 18:936-43

92. Goldfischer S, Johnson AB, Essner E, Moore C, Ritch RH. 1973. J. Histochem. Cytochem. 21:972-77

93. Bowen P, Lee CSM, Zellweger H, Lindenberg R. 1964. Bull. Johns Hopkins Hosp. 114:402-14

94. Lazarow PB, Moser HW. 1989. Disorders of Peroxisome Biogenesis, pp. 1479-509. New York: McGraw-Hill

95. Santos MJ, Imanaka T, Shio H, Small GM, Lazarow PB. 1988. Science 239:153638

96. Walton PA, Gould SJ, Feramisco JR, Subramani S. 1992. Mol. Cell. Biol. 12:53141

97. Wendland M, Subramani S. 1993. J. Clin. Invest. 92:2462-68

98. Motley A, Hettema E, Distel B, Tabak H. 1994. J. Cell Biol. 125:755-67

99. Slawecki ML, Dodt G, Steinberg S, Moser AB, Moser HW, et al. 1995. J. Cell Sci. 108:1817-29
100. Tsukamoto T, Miura S, Fujiki Y. 1991. Nature 350:77-81

101. Shimozawa N, Tsukamoto T, Suzuki Y, Orii T, Shirayoshi Y, et al. 1992. Science 255:1132-34

102. Dodt G, Braverman N, Valle D, Gould SJ. 1996. Ann. NY Acad. Sci. 804:516-23

103. Soukupova M, Sprenger C, Gorgas K, Kunau WH, Dodt G. 1999. Eur. J. Cell Biol. 78:357-74

104. Abe I, Fujiki Y. 1998. Biochem. Biophys. Res. Commun. 252:529-33

105. Portsteffen H, Beyer A, Becker E, Epplen C, Pawlak A, et al. 1997. Nat. Genet. 17:449-52

106. Reuber BE, Germain LE, Collins CS, Morrell JC, Ameritunga R, et al. 1997. Nat. Genet. 17:445-48

107. Tamura S, Okumoto K, Toyama R, Shimozawa N, Tsukamoto T, et al. 1998. Proc. Natl. Acad. Sci. USA 95:4350-55

108. Fransen M, Brees C, Baumgart E, Vanhooren JC, Baes M, et al. 1995. J. Biol. Chem. 270:7731-36

109. Fukuda S, Shimozawa N, Suzuki Y, Zhang Z, Tomatsu S, et al. 1996. Am. J. Hum. Genet. 59:1210-20

110. Yahraus T, Braverman N, Dodt G, Kalish JE, Morrell JC, et al. 1996. EMBO J. 15: 2914-23

111. Warren DS, Morrell JC, Moser HW, Valle D, Gould SJ. 1998. Am. J. Hum. Genet. 63:347-59

112. Okumoto K, Itoh R, Shimozawa N, Suzuki Y, Tamura S, et al. 1998. Hum. Mol. Genet. 7:1399-405

113. Chang CC, Lee WH, Moser H, Valle D, Gould SJ. 1997. Nat. Genet. 15:38588

114. Okumoto K, Shimozawa N, Kawai A, Tamura S, Tsukamoto T, et al. 1998. Mol. Cell. Biol. 18:4324-36

115. Liu YF, Bjorkman J, Urquhart A, Wanders RJA, Crane DI, et al. 1999. Am. J. Hum. Genet. 65:621-34

116. Shimozawa N, Suzuki Y, Zhang Z, Imamura A, Toyama R, et al. 1999. Hum. Mol. Genet. 8:1077-83 
117. Honsho M, Tamura S, Shimozawa N, Suzuki Y, Kondo N, et al. 1998. Am. J. Hum. Genet. 63:1622-30

118. Mosser J, Douar AM, Sarde CO, Kioschis P, Feil R, et al. 1993. Nature 361:726-30

119. Sacksteder KA, Morrell JC, Wanders RJA, Matalon R, Gould SJ. 1999. J. Biol. Chem. 274:24461-68

120. Houten SM, Kuis W, Duran M, de Koning TJ, van Royen KA, et al. 1999. Nat. Genet. 22:175-77

121. Danpure CJ. 1994. Clin. Invest. 72:72527

122. van Grunsven EG, Mooijer PAW, Aubourg P, Wanders RJA. 1999. Hum. Mol. Genet. 8:1509-16

123. van Grunsven EG, van Berkel E, Ijlst L, Vreken P, de Klerk JB, et al. 1998. Proc. Natl. Acad. Sci. USA 95:2128-33
124. Jansen GA, Ferdinandusse S, Skjeldal $\mathrm{OH}$, Stokke O, de Groot CJ, et al. 1998. J. Inherit. Metab. Dis. 21:28891

125. Ofman R, Hettema EH, Hogenhout EM, Caruso U, Muijsers AO, et al. 1998. Hum. Mol. Genet. 7:847-53

126. de Vet EC, van den Broek BT, van den Bosch H. 1997. Biochim. Biophys. Acta 1346:25-29

127. Wen JK, Osumi T, Hashimoto T, Ogata M. 1990. J. Mol. Biol. 211:383-93

128. Poll-The BT, Roels F, Ogier H, Scotto J, Vamecq J, et al. 1988. Am. J. Hum. Genet. 42:422-34

129. Schram AW, Goldfischer S, van Roermund CW, Brouwer-Kelder EM, Collins J, et al. 1987. Proc. Natl. Acad. Sci. USA 84:2494-96 


\section{CONTENTS}

STILL LOOKING FOR THE IVORY TOWER, Howard K. Schachman

CRYPTOCHROME: The Second Photoactive Pigment in The Eye and Its Role in Circadian Photoreception, Aziz Sancar

PROTEIN GLUCOSYLATION AND ITS ROLE IN PROTEIN

FOLDING, Armando J. Parodi

SPINDLE ASSEMBLY IN ANIMAL CELLS, Duane A. Compton

CHROMOSOME COHESION, CONDENSATION, AND

SEPARATION, Tatsuya Hirano

CYCLOOXYGENASES: Structural, Cellular, and Molecular Biology, William L. Smith, David L. DeWitt, and R. Michael Garavito

TWO-COMPONENT SIGNAL TRANSDUCTION, Ann M. Stock, Victoria L. Robinson, and Paul N. Goudreau

APOPTOSIS SIGNALING, Andreas Strasser, Liam O'Connor, and Vishva M. Dixit

YEAST HOMOTYPIC VACUOLE FUSION: A Window on Organelle Trafficking Mechanisms, William Wickner and Albert Haas

STRUCTURAL INSIGHTS INTO MICROTUBULE FUNCTION, Eva Nogales

AUTOPHAGY, CYTOPLASM-TO-VACUOLE TARGETING PATHWAY, AND PEXOPHAGY IN YEAST AND MAMMALIAN

CELLS, John Kim and Daniel J. Klionsky

COUPLING OF OPEN READING FRAMES BY TRANSLATIONAL BYPASSING, Alan J. Herr, John F. Atkins, and Raymond F. Gesteland

PROTEIN TYROSINE KINASE STRUCTURE AND FUNCTION, Stevan R. Hubbard and Jeffrey H. Till

IMPORT OF PEROXISOMAL MATRIX AND MEMBRANE

PROTEINS, S. Subramani, Antonius Koller, and William B. Snyder

PLATELET-ACTIVATING FACTOR AND RELATED LIPID

MEDIATORS, Stephen M. Prescott, Guy A. Zimmerman, Diana M.

Stafforini, and Thomas M. McIntyre

PROTEIN SPLICING AND RELATED FORMS OF PROTEIN

AUTOPROCESSING, Henry Paulus

DNA REPLICATION FIDELITY, Thomas A. Kunkel and Katarzyna

Bebenek

497

RECEPTOR BINDING AND MEMBRANE FUSION IN VIRUS

ENTRY: The Influenza Hemagglutinin, John J. Skehel and Don C. Wiley 
MECHANISMS AND CONTROL OF MRNA DECAPPING IN

Saccharomyces cerevisiae, Morgan Tucker and Roy Parker

RIBOZYME STRUCTURES AND MECHANISMS, Elizabeth A.

Doherty and Jennifer A. Doudna

597

AMINOACYL-TRNA SYNTHESIS, Michael Ibba and Dieter Söll

617

STRUCTURE AND FUNCTION OF HEXAMERIC HELICASES, $S$. $S$.

Patel and K. M. Picha

651

CLATHRIN, Tomas Kirchhausen

699

MEDIATOR OF TRANSCRIPTIONAL REGULATION, Lawrence C.

Myers and Roger D. Kornberg

729

CRITICAL ANALYSIS OF ANTIBODY CATALYSIS, Donald Hilvert

GTPASE-ACTIVATING PROTEINS FOR HETEROTRIMERIC G

PROTEINS: Regulators of G Protein Signaling (RGS) and RGS-Like

Proteins, Elliott M. Ross and Thomas M. Wilkie

795

REGULATION OF CHROMOSOME REPLICATION, Thomas J. Kelly

and Grant W. Brown

829

HELICAL MEMBRANE PROTEIN FOLDING, STABILITY, AND

EVOLUTION, Jean-Luc Popot and Donald M. Engelman

881

SYNTHESIS OF NATIVE PROTEINS BY CHEMICAL LIGATION,

Philip E. Dawson and Stephen B. H. Kent

923

SWINGING ARMS AND SWINGING DOMAINS IN

MULTIFUNCTIONAL ENZYMES: Catalytic Machines for Multistep

Reactions, Richard N. Perham

961

STRUCTURE AND FUNCTION OF CYTOCHROME bc

COMPLEXES, Edward A. Berry, Mariana Guergova-Kuras, Li-shar

Huang, and Antony R. Crofts

1005 